\title{
Use of the Inverse Slope Method for the Characterization of Geometry of Basement Aquifers: Case of the Department of Bouna (Ivory Coast)
}

\author{
Rock Armand Michel Bouadou', Kouamé Auguste Kouassi ${ }^{1}$, \\ Francis Williams Kouassi ${ }^{1}$, Adama Coulibaly ${ }^{2}$, Théophile Gnagne ${ }^{1}$ \\ ${ }^{1}$ Laboratory of Geosciences and Environment, UFR of Sciences and Management of the Environment, University of Nangui Abrogoua, \\ Abidjan, Ivory Coast \\ ${ }^{2}$ Department of Science and Technology of Water and Environmental Engineering, UFR of Earth Sciences and Mineral Resources, \\ University of Félix Houphouët-Boigny, Abidjan, Ivory Coast \\ Email: rockarmand22@gmail.com
}

How to cite this paper: Bouadou, R. A. M., Kouassi, K. A., Kouassi, F. W., Coulibaly, A., \& Gnagne, T. (2019). Use of the Inverse Slope Method for the Characterization of Geometry of Basement Aquifers: Case of the Department of Bouna (Ivory Coast). Journal of Geoscience and Environment Protection, 7, 166-183.

https://doi.org/10.4236/gep.2019.76014

Received: April 24, 2019

Accepted: June 27, 2019

Published: June 30, 2019

Copyright $\odot 2019$ by author(s) and Scientific Research Publishing Inc. This work is licensed under the Creative Commons Attribution International License (CC BY 4.0).

http://creativecommons.org/licenses/by/4.0/

\begin{abstract}
The inverse slope method (ISM) was used to interpret electric sounding data to determine the geoelectric parameters of the alteration zones (continuous media) and rocky environments (discontinuous environments) of the Bouna Department. Having both qualitative and quantitative interpretation, the inverse slope method (ISM) has the ability to determine the different geoelectric layers while characterizing their resistivities and true thicknesses. In the Bouna department, this method allowed us to count a maximum of four (4) geoelectric layers with a total thickness ranging from $12.99 \mathrm{~m}$ to $24.66 \mathrm{~m}$. The alteration thicknesses calculated by the ISM in comparison with those measured in the boreholes showed a linear agreement of the coefficient of determination $R^{2}=0.8269$ with the support of the Nash criterion which showed that this method gave thicknesses of alteration close to $76.76 \%$ of that obtained during the drillings.
\end{abstract}

\section{Keywords}

Inverse Slope, Electric Sounding, Geometry of Aquifers, Bouna, Ivory Coast

\section{Introduction}

Water, a source of life, is not just a slogan, but rather a very important commodity in the daily life of the human being. To satisfy human consumption, ground- 
water is more desirable than surface water. This is justified by the fact that groundwater resources are protected from anthropogenic pollution. However, to access this underground resource, knowledge of the geology of the geological formations is necessary for a good choice of drilling sites. As a result, we used the technique of electrical sounding which is a vertical investigation to identify the different layers of the subsoil.

Despite the existence of catchment work (boreholes and wells), the localities of Bouna department are very often deprived of drinking water, especially during the dry season. This deprivation of drinking water is often caused by population growth and the effects of climate change. As a result, there is an increase in water requirements for various household uses. From this observation, it is undeniable that the satisfaction of people's drinking water needs is closely linked to a better knowledge of aquifers.

However, the interpretation of these electrical survey data is done in situ and improved by expensive software that is not always available to develop country research institutes such as Côte d'Ivoire. Thus, the method of the inverse slope suggested by (Sankarnaryan \& Ramanujachary, 1967), free of access and easy to use, and take over Mondal et al. (2008), Karuppannan (2015), Poongothai \& Sridhar (2017) in India and Kouassi et al. (2017) in Côte d'Ivoire in granitic formations, will be tested in the Bouna department which presents similar geological contexts.

The main objective of this study is to verify the efficiency of the inverse slope method (ISM) for the interpretation of electrical sounding data to determine the geoelectric parameters of geological structures in the basement area, crystalline of the department of Bouna.

\section{General Information on the Area of Study}

\subsection{Presentation of the Study Area}

The Bouna Department is located in the northeastern part of Côte d'Ivoire between longitudes $2^{\circ} 36^{\prime}$ and $4^{\circ} 18^{\prime}$ West and latitudes $8^{\circ} 29^{\prime}$ and $9^{\circ} 48^{\prime}$ North. It is administratively attached to the Zanzan District and the Bounkani Region. The city of Bouna which is the chief town of the region, is located $603 \mathrm{~km}$ north of Abidjan. It is one of the gateways to the Comoé National Park.

The department of Bouna covers an area of $15,380 \mathrm{~km}^{2}$ and is limited (Figure

1) (CGES, 2016):

- in the east by the Ivorian-Ghanaian border and the black Volta;

- in the South, by the Bondoukou and Nassian Departments;

- in the West, by the Departments of Dabakala and Ferkessedougou;

- in the North, by the Departments of Doropo and Tehini.

\subsection{Vegetation, Relief and Climate}

The vegetation belongs to the Sudanese domain, in transition between the Sudanese sectors for the most part and the sub-Sudanese in the West, South and 


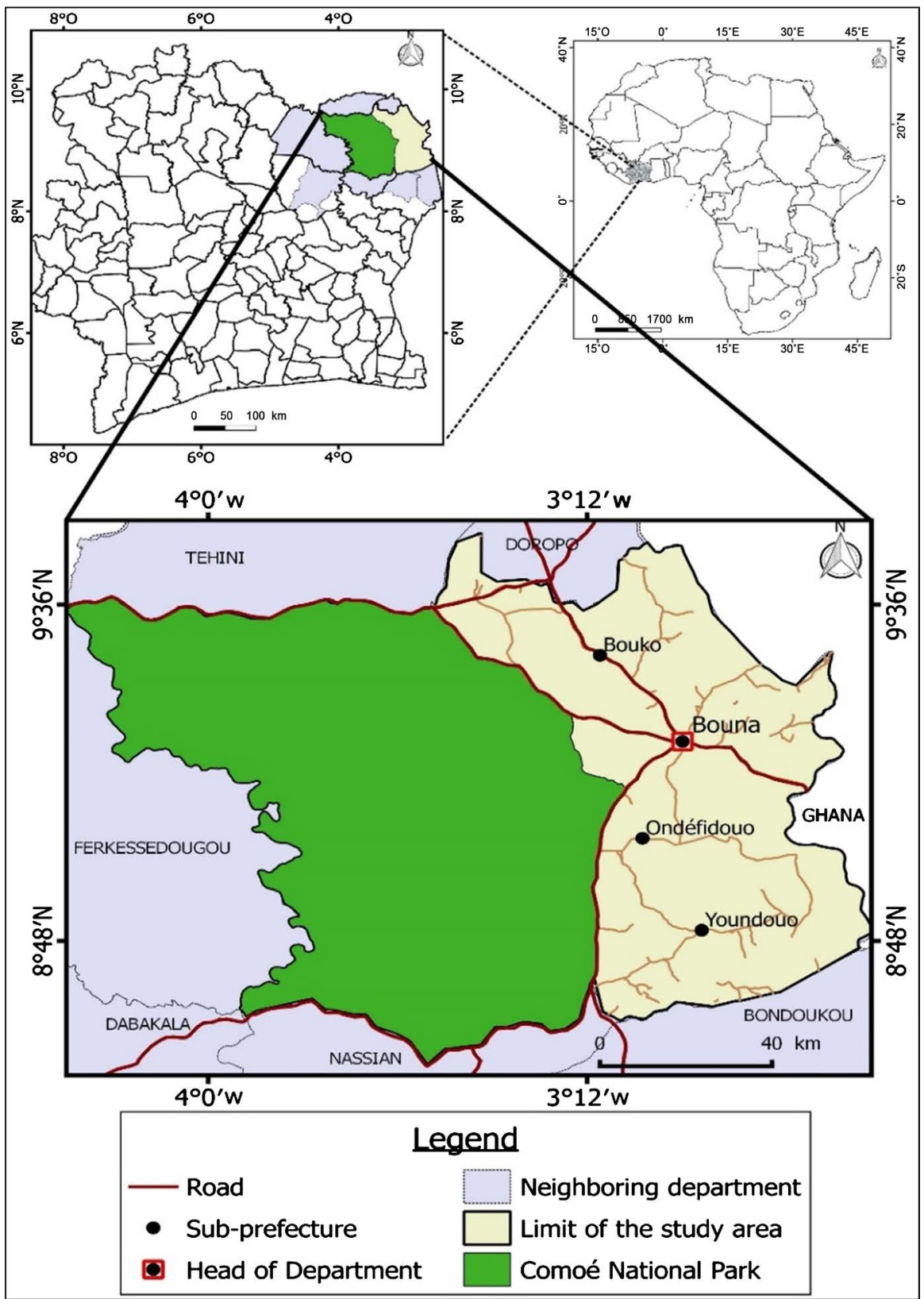

Figure 1. Geographical location of the study area.

Southwest. The vegetation types of this area are: dry forest and/or wooded savannah, tree and/or shrub savannah and dry dense forest.

The relief is heterogeneous and consists of plateaus and mountains. The plateaux are inclined in the North-South direction (Kouadio, 2013) and the altitudes are between $185 \mathrm{~m}$ and $339 \mathrm{~m}$. However, from the South Center to the North Center, which is a ridge zone, the boundary between the Comoé and Black Volta watersheds is at altitudes between $339 \mathrm{~m}$ and $570 \mathrm{~m}$.

The climate is tropical transitional (UNEP-GEF Volta Project, 2008) or Sudanese climate. There are two well-differentiated seasons between equatorial and hot desert type climates. The average temperature varies between $28^{\circ} \mathrm{C}$ (Febru- 
ary, March and April) and $24^{\circ} \mathrm{C}$ (August). The maximum temperature varies from $27^{\circ} \mathrm{C}$ to $35^{\circ} \mathrm{C}$ and the months of February and March are the hottest months of the year with an average of $28^{\circ} \mathrm{C}$.

\subsection{Geological and Hydrogeological Contexts}

Located in the Paleoproterozoic domain, the geological formations of the Bouna Department were structured during the eburnian orogeny. Thus, the geological formations are marked by an alternation of lower Proterozoic complex, birimian and antebirimian series (Figure 2).

- The lower Proterozoic complex is represented by all the orogenic plutons, the concordant and discordant granitoids.

- The Birimian series includes volcano-sedimentary and filling formations.

- The antebirimian or Archean consists only of migmatites.

From a hydrogeological point of view, two types of aquifers are distinguished: aquifers of alterites and aquifers of fissures. Alterites are formations that result from physico-chemical alteration and erosion of the source rock. Located above the crystalline and crystallophyllian basement, these alterite reservoirs are composed of clayey sand and granitic arena. The alterites of granular formations consist of clays, sands, sandy clays and lateritic clays.

Basement aquifers develop in areas of alteration and/or fissured granites. They are protected against seasonal fluctuations and most types of pollution. These reservoirs are exploited by catchment works (wells and boreholes) to meet the daily needs of the population. The formation possibilities of these reservoirs are related to the density of the rupture of these reservoirs (Savadogo, 1984; Biemi, 1992).

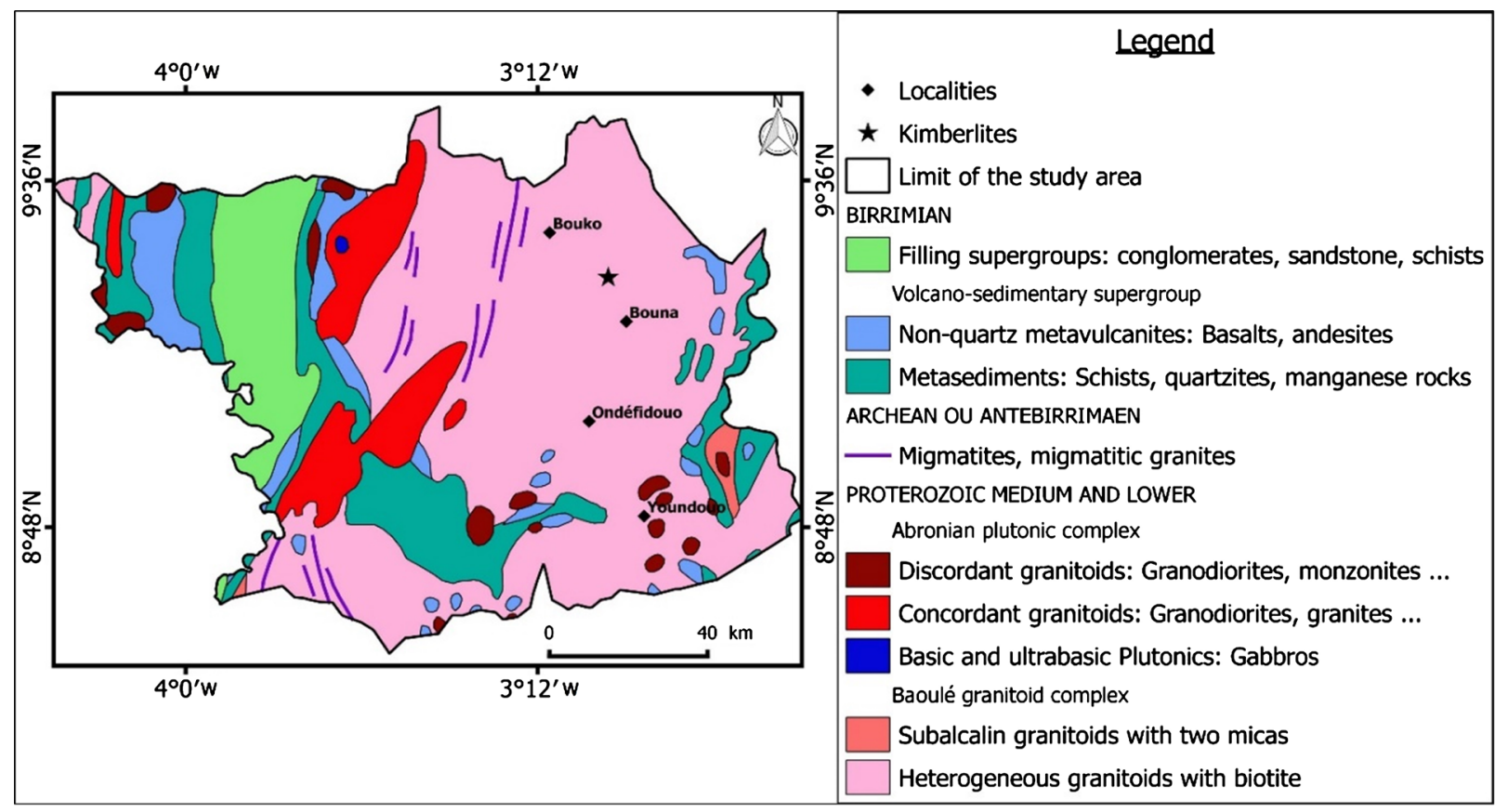

Figure 2. Geological map of the study area (Tagini, 1971). 


\section{Materials and Methods}

\subsection{Data and Materials}

For the realization of this study, we used a resistimeter of Syscal Pro type of Iris Instruments. It allows the realization of the techniques of electric drag as well as those of electrical sounding. It has a screen and a digital control board. However, its use for geophysical prospecting is conditioned by the combination of several useful devices and accessories. These are: a 12-volt battery, an amplifier of 200 to 1000 volts, twelve (12) stainless steel electrodes, four (4) coils of electric cable, a compass, a GPS, pliers, two (2) decametres, two (2) hammers and electrical wires.

In the study environment twenty-one (21) electrical soundings were performed. These resulted in the installation of 21 boreholes for the supply of the localities of the department of Bouna.

\subsection{Collection of Data}

Measuring the resistivity of a structure is done by injecting electric current into it, by means of two injection or emission electrodes $(A$ and $B$ ) and by measuring the difference of potential created by the passage current by means of two other measuring or receiving electrodes ( $M$ and $N$ ) (Same, 1999; Chapellier, 2001; Marescot, 2004; Baltassat et al., 2005; Bakkali \& Amrani, 2006; Collot, 2010; Sombo, 2012; Coulibaly, 2014). This measurement is based on a quadrupole device $(A M N B)$ (Figure 3). Since the laws governing electrical phenomena are linear, it is possible to add algebraically the potentials created by current sources ( $A$ and $B)$. This measurement is attributed to the center of the device (generally at the center of the electrodes $M$ and $N$ ), although it actually concerns a volume of soil depending on the distance between the electrodes and their implantation geometry. The apparent resistivity of the subsoil is written:

$$
\rho_{a}=k \times \Delta V_{M N} / I
$$

with: $\rho_{a}$ : apparent resistivity in $\mathrm{Ohm} \cdot \mathrm{m}$ or $\Omega \cdot \mathrm{m}$;

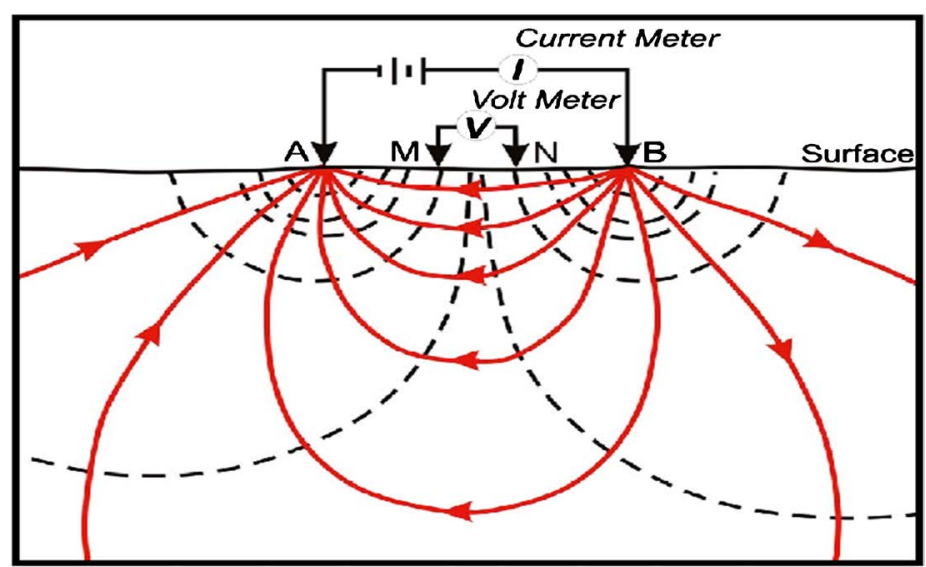

Figure 3. Principle of measurement of the apparent resistivity of the subsoil using a quadripole device (Clark \& Page, 2011). 
$\Delta V_{M N}$ potential difference created in volts or millivolt;

$I$ : intensity of current in ampere or milliamperes;

$K$ : geometric factor that is written:

$$
k=2 \pi \times(1 / A M-1 / B M-1 / A N+1 / B N)^{-1}
$$

In our study, the Schlumberger quadrupole device was used for the realization of vertical electrical soundings. Its principle was to vary the distances of the current injection electrodes ( $A$ and $B$ ) for electrode distances ( $M$ and $N$ ) of constant potentials. These vertical electrical soundings are made with distances $(A B / 2)$ ranging from 1 to $150 \mathrm{~m}$ and $M N / 2$ from 0.75 to $10 \mathrm{~m}$.

\subsection{Inverse Slope Method (ISM)}

Some empirical, analytical and numerical methods have been developed to determine the resistivity of different subterranean formations (Tagg, 1934; Mooney \& Wetzel, 1956; Orellana \& Mooney, 1966; Ghosh, 1971; Patra \& Nath, 1999; Mondal et al., 2008). In the meantime, Sankarnaryan \& Ramanujachary (1967) have shown that the field equation can be directly solved to obtain the resistivities and thicknesses of the subsurface layers from the field data. They suggested a method for identifying underground formations by studying variations in electrical parameters. This is the inverse slope method (ISM).

This method was originally proposed for the interpretation of data from the Wenner survey. According to this approach, the inverse of the resistance graph $(1 / R)$ is first constructed as a function of the inter-electrode distance " $a$ ". Then, from the points defining this graph, we identify segments of lines. Each segment represented a layer and the intersections of the segments correspond to the depths of the layers.

In this work, we have adapted this method to the electrode configuration of the Schlumberger device because it depends on the arrangement of the electrodes $A, B, M$ and $N$.

From the apparent resistivity data $\rho_{a}$ and measured $A B / 2$ distances, arithmetic-scale graphs were constructed using the Excel software. We have reported on the abscissa the half distance $A B / 2$ and on the ordinate the ratio of the half distance on the apparent resistivity $\left(A B / 2 / \rho_{a}\right)$. These graphs allowed us to generate line segments joining various points (Figure 4 ). Thus, each segment represented a layer with a linear equation, hence the number of segments equals the number of layers revealed in the survey area and the intersections of these segments indicated the depths of the interfaces between the underground layers on the $\mathrm{X}$-axis (Sanjiv, 2010). On the other hand, the inverse of the slope of the equation of a segment gave directly the true resistivity of the layer and the intersections of the projected segments on the X-axis were multiplied by $2 / 3$ to obtain the depths of the interfaces.

For the determination of true resistivity values and layer thicknesses, the procedure to be followed was as follows:

- Case of layer 1: determination of $\rho_{1}$ and $H_{1}$ 


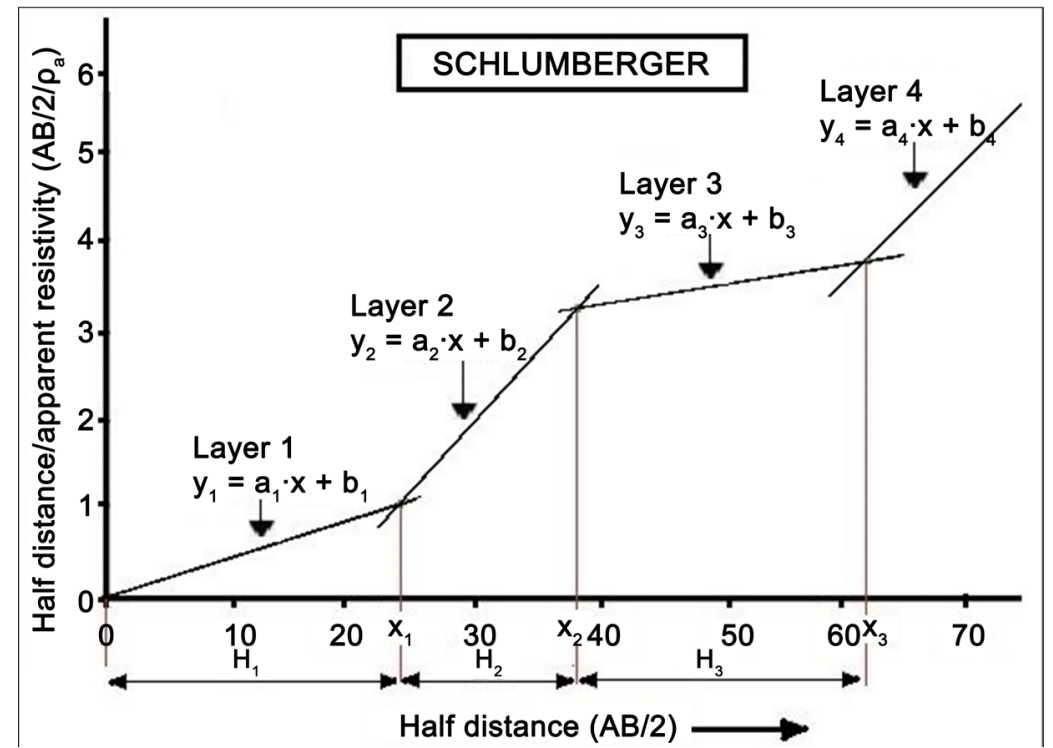

Figure 4. Graph of the inverse slope method according to the Schlumberger device.

The first segment had a line of equation $y_{1}=a_{1} \cdot x+b_{1}$. This equation had a slope that is equal to $a_{1}$. However the true resistivity is the inverse of this slope, so

$$
\rho_{1}=1 /\left|a_{1}\right|
$$

For the determination of $H_{1}$, we notice that in $x_{1}$, at the intersection of the segments of layers 1 and 2 , the equations $y_{1}$ et $y_{2}$ equalize $\left(y_{1}=y_{2}\right)$, hence $a_{1} \cdot x_{1}+b_{1}=a_{2} \cdot x_{1}+b_{2}$. So in $x_{1}$, we have $H_{1}=x_{1}$ and the equation that calculates $\mathrm{H}_{1}$ is (4).

$$
H_{1}=\left(\left(b_{2}-b_{1}\right) /\left(a_{1}-a_{2}\right)\right) \times 2 / 3
$$

with: $a_{1}$ and $a_{2}$ : represent the slopes of segments 1 and $2 ; b_{1}$ and $b_{2}$ : are constants of the respective equations $y_{1}$ and $y_{2}$.

- Case of layer 2: determination of $\rho_{2}$ and $H_{2}$

As in the previous case, the resistivity value is the inverse of the slope of the layer 2 segment. So the true resistivity of the second layer is:

$$
\rho_{2}=1 /\left|a_{2}\right| \text {. }
$$

At the intersection of the segments of layers 2 and $3, y_{2}=y_{3}$, where $a_{2} \cdot x_{2}+b_{2}=a_{3} \cdot x_{2}+b_{3}$. So in $x_{2}, H_{2}$ is determined by (6).

$$
H_{2}=\left(\left(b_{3}-b_{2}\right) /\left(a_{2}-a_{3}\right)\right) \times 2 / 3
$$

with: $a_{2}$ and $a_{3}$ : represent the slopes of segments 2 and $3 ; b_{2}$ and $b_{3}$ : are constants of the respective equations $y_{2}$ and $y_{3}$.

- Case of layer 3: détermination of $\rho_{3}$ and $H_{3}$

In the same principles as the previous calculations, the values of $\rho_{3}$ and $H_{3}$ are determined by (7) and (8)

$$
\rho_{3}=1 /\left|a_{3}\right|
$$




$$
H_{3}=\left(\left(b_{4}-b_{3}\right) /\left(a_{3}-a_{4}\right)\right) \times 2 / 3
$$

with: $a_{3}$ and $a_{4}$ : represent the slopes of segments 3 and $4 ; b_{3}$ and $b_{4}$ : are constants of the respective equations $y_{3}$ and $y_{4}$.

In general, after having determined the straight line equations for each layer, the following formulas allowed us to calculate the values of the true resistivities and the depths of the layer interfaces.

True resistivity $\rho_{n}$

$$
\rho_{n}=1 /\left|a_{n}\right|
$$

Depths of the interfaces of the layers $H_{n}$

$$
H_{n}=\left(\left(b_{n+1}-b_{n}\right) /\left(a_{n}-a_{n+1}\right)-\left(b_{n}-b_{n-1}\right) /\left(a_{n-1}-a_{n}\right)\right) \times 2 / 3
$$

where $n$ indicates the number of the segments ( $n=1,2,3, \cdots$ etc.)

In the case of the first segment, the value of the first thickness of the layer is equal to the value of the first intersection of the projected segments on the $\mathrm{X}$-axis. So $H_{1}$ is equal to $X_{1}\left(H_{1}=2 x_{1} / 3\right)$ of (3).

\subsection{Optimization Criterion Function}

The alteration thicknesses are estimated from the interpretation of electric sounding data by the inverse slope method. The results of the calculated thicknesses of alterites will be compared with the results of the thicknesses of deterioration of the drillings in order to verify the degree of reliability of these methods of interpretation. The criterion function chosen is that proposed by Nash \& Sutclife (1970). This criterion based on the mean squared error is very commonly used as an objective function (Coulibaly, 2014). The criterion function or numerical criterion is the numerical object of reference during the calibration (automatic or manual) of a model. This function must tend to a given value (minimum, maximum or constant) when the calculated values tend towards the observed values. It is defined by (11).

$$
\text { Nash }=100 \times\left(1-\left(\left(\sum_{i=1}^{n}\left(E A_{i o b s}-E A_{i C a l}\right)^{2}\right) /\left(\sum_{i=1}^{n}\left(E A_{i o b s}-E A_{i C a l}\right)^{2}\right)\right)\right)
$$

with: $E A_{\text {iObs }}$ Thickness of alteration observed;

$E A_{i C a i}$ Thickness of alteration calculated or simulated;

$E A_{\text {Omor }}$ Mean thickness of alteration observed.

The performance of the model is judged according to the values taken by the Nash criterion (Yao et al., 2007):

- Nash $\geq 90 \%$ : the model is excellent;

- $80 \%<$ Nash $<90 \%$ : the model is very satisfactory;

- $60 \%<$ Nash $<80 \%$ : the model is satisfactory;

- Nash $<60 \%$ : the model is bad.

The model is considered efficient when the calculated thicknesses are close to the observed thicknesses, that is to say when the value of the Nash criterion is close to $100 \%$. 
A Nash criterion of less than $60 \%$ is the indication of a faulty model (Bodian et al., 2012). This implies that it does not give a satisfactory concordance between the observed and simulated thicknesses.

\section{Results and Discussion}

\subsection{Interpretation of Geoelectric Data}

Figure 5 presents a graph relating to the electrical sounding conducted in the locality of Bipirdouo. This graph highlighted three (3) geoelectric layers materialized by distinct segments.

The first layer has an equation of $y_{1}=0.0284 x-0.0421$, it allowed us to determine the first true resistivity $\left(\rho_{1}\right)$ of $35.21 \Omega \cdot \mathrm{m}$ and a thickness $\left(H_{1}\right)$ of $9.21 \mathrm{~m}$. For the second right layer of equation $y_{2}=0.0066 x+0.2591$, the true resistivity $\left(\rho_{2}\right)$ is $151.52 \Omega \cdot \mathrm{m}$ and its thickness $\left(H_{2}\right)$ is $11.44 \mathrm{~m}$. Finally, the third layer of equation $y_{3}=-0.0016 x+0.5131$, gave us a true resistivity $\left(\rho_{3}\right)$ of $625 \Omega \cdot \mathrm{m}$ with an infinite thickness.

Figure 5 showed us that the interface between the alterite and granitic media was the intersection of the last and second last layers. By summation of the calculated thicknesses $\left(H_{1}+H_{2}\right)$, the boundary between the alterites and the granitic medium was $20.65 \mathrm{~m}$ deep.

- Case of the locality of Dasseho

As in the locality of Bipirdouo, Figure 6 shows the interpretative graph corresponding to the electric sounding of the locality of Dasseho.

The graph in Figure 6 has allowed us to count four (4) geoelectric layers that are each represented by segments. In the same order of the description of Figure 5 , the true resistivity values $(\rho)$ and the thicknesses $(H)$ of the layers are:

Layer 1: Equation right $\quad y_{1}=0.0489 x-0.0078$

$\rho_{1}=20.45 \Omega \cdot \mathrm{m}$

$H_{1}=4.54 \mathrm{~m}$

Layer 2: equation right

$y_{2}=0.0147 x+0.225$

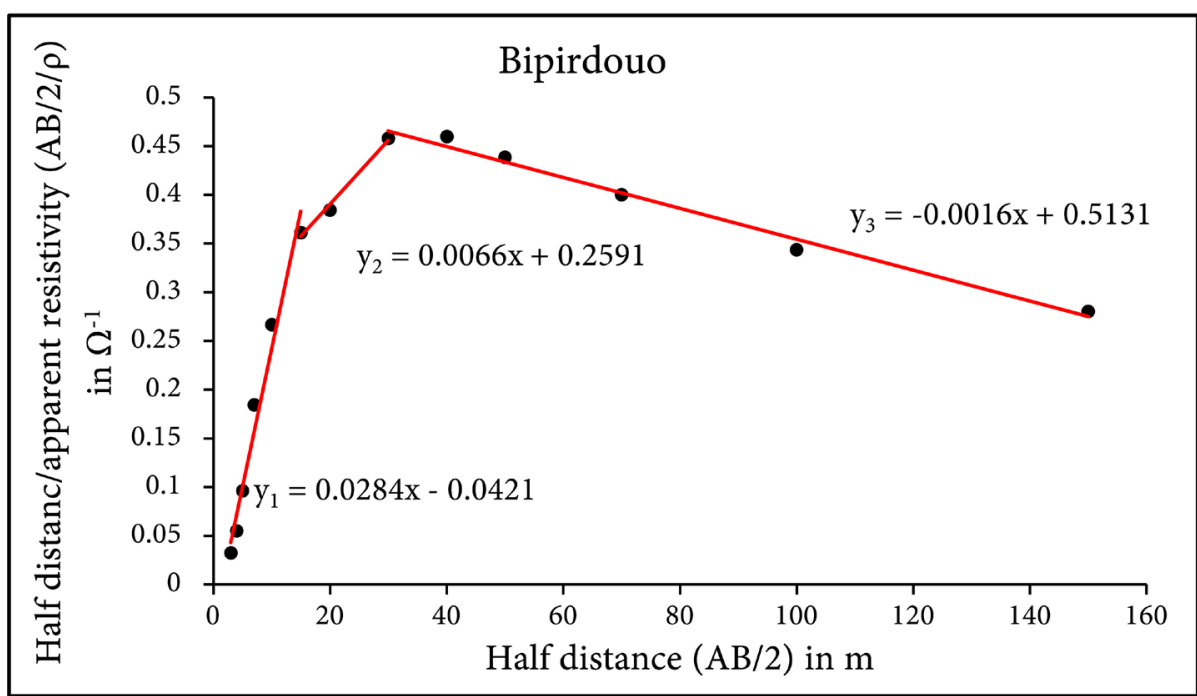

Figure 5. Interpretation graph of the Bipirdouo electrical sounding. 


$$
\begin{array}{ll}
\rho_{2}=68.03 \Omega \cdot \mathrm{m} & H_{2}=9 \mathrm{~m} \\
\text { Layer 3: Equation right } & y_{3}=0.0069 x+0.3834 \\
\rho_{3}=144.93 \Omega \cdot \mathrm{m} & H_{3}=10.7 \mathrm{~m} \\
\text { Layer 4: Equation right } & y_{4}=0.0005 x+0.6161 \\
\rho_{4}=2000 \Omega \cdot \mathrm{m} & H=\text { infinite }
\end{array}
$$

After determining the true resistivities and the thicknesses of each layer, it follows that the total thickness of alteration is $24.24 \mathrm{~m}$. This value represents the depth at which the alteration zone is in contact with the granite.

- Case of the locality of Garankodouo

In the same order as the locations above, we have enumerated two (2) geoelectric layers that are represented by segments (Figure 7). The values of the true resistivities $(\rho)$ and thicknesses $(H)$ of these layers are:

Layer 1: Equation right $\quad y_{1}=0.0143 x-0.0236$

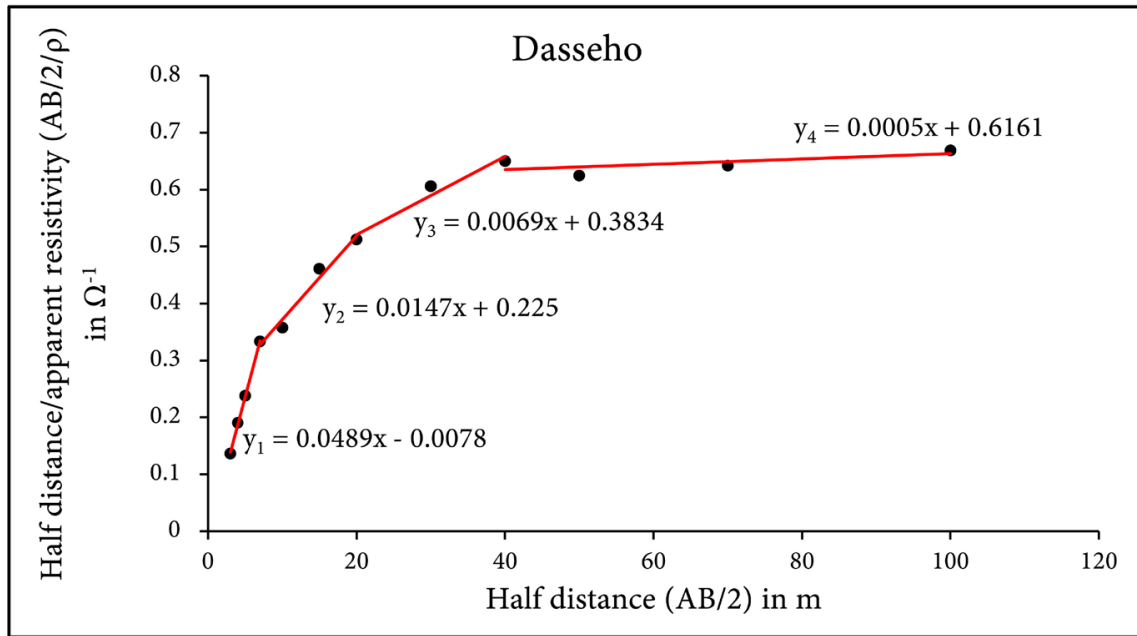

Figure 6. Interpretation graph of the Dasseho electric sounding.

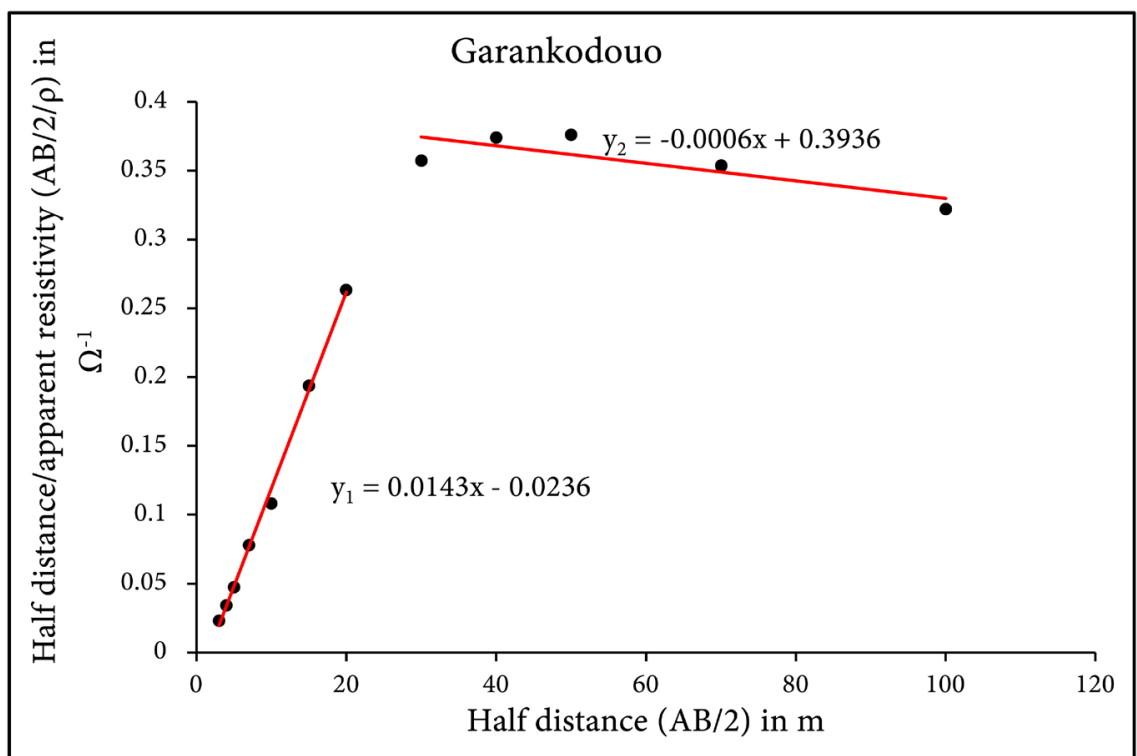

Figure 7. Graphique d'interprétation du sondage électrique de Garankodouo. 


$$
\begin{array}{ll}
\rho_{1}=69.93 \Omega \cdot \mathrm{m} & H_{1}=18.67 \mathrm{~m} \\
\text { Layer 2: Equation right } & y_{2}=-0.0006 x+0.3936 \\
\rho_{2}=1666.67 \Omega \cdot \mathrm{m} & H_{2}=\text { infinite }
\end{array}
$$

The total alteration thickness of this locality is estimated at $18.67 \mathrm{~m}$.

The other results of the inverse slope method are given in the Appendix section (Appendix 1 and Appendix 2) and the number of geoelectric layers in the study area varies from two (2) to four (4) horizons.

\subsection{Descriptive Study of the Thicknesses of Alterites of Boreholes and Those of Vertical Electrical Sounding}

In the department of Bouna, the surveyed localities benefited from twenty-one (21) vertical electrical soundings which favored implantation of twenty-one (21) boreholes.

The descriptive analysis of the results of the thicknesses of alterite show that they vary from $6.2 \mathrm{~m}$ to $40.74 \mathrm{~m}$ with an average of $22.69 \mathrm{~m}$ for drilling and from $12.99 \mathrm{~m}$ to $38.20 \mathrm{~m}$ with an average of $24.66 \mathrm{~m}$ for electrical soundings (Table 1 ).

This figure shows that the results of the thicknesses of alterites measured and calculated by the inverse slope method are in the same class order with a margin of error of $8.68 \%$ on the mean.

EA alteration thicknesses are grouped into classes of $10 \mathrm{~m}$ intervals. Thus, we note that the alteration thicknesses into classes of $10 \mathrm{~m}$ intervals drilling and the inverse slope method are dominated by the EA class of 20 - $30 \mathrm{~m}$ delimited by red discontinuous lines (Figure 8). This dominance of the class 20 - 30 m results

Table 1. Descriptive analysis of the thicknesses of alterite (EA).

\begin{tabular}{cccc}
\hline & Mean & Minimum & Maximum \\
\hline EA Drilling & 22.69 & 6.20 & 40.74 \\
EA ISM & 24.66 & 12.99 & 38.20
\end{tabular}

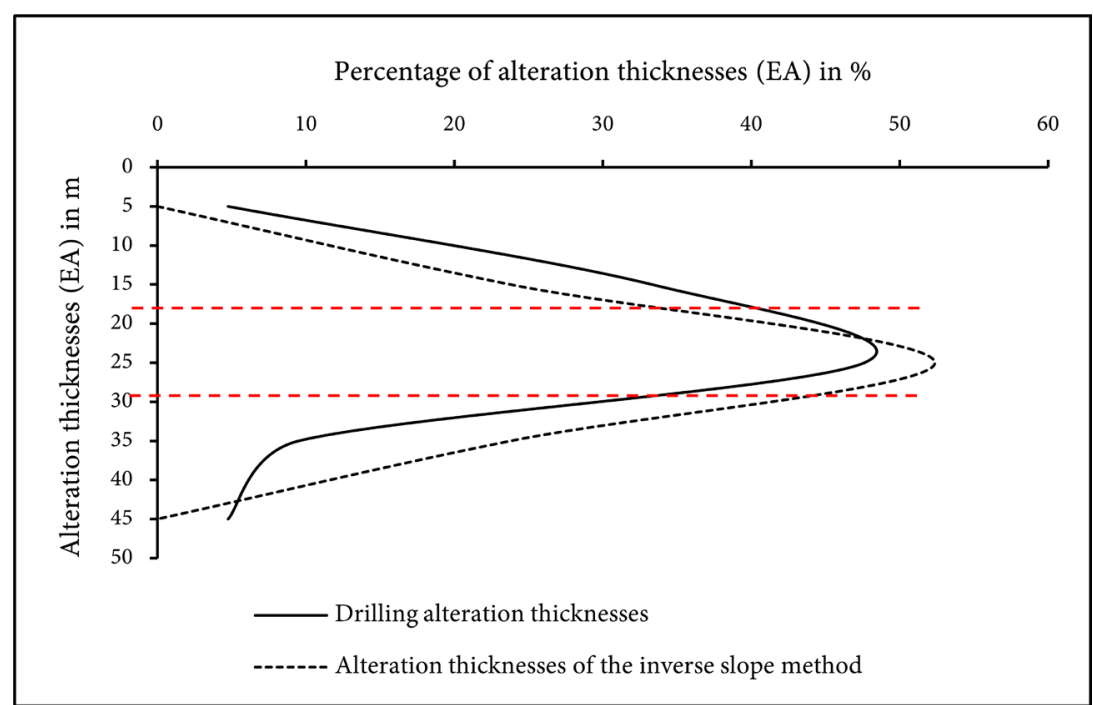

Figure 8. Graph illustrating the ranges of the most representative alteration thicknesses. 
in percentages of $48 \%$ for the thicknesses of alteration of the drillings and $52 \%$ for those of the method of the inverse slope.

\subsection{Relationship between the Measured Thicknesses of Alterites and Those Calculated by ISM}

The knowledge of the alteration thickness is a determining criterion in the implantation of water wells because it allows us to identify the depth of the interface between the alteration zones and the granitic basement. Thus a study on the relationship between the alteration thickness calculated from electrical soundings by the inverse slope method (ISM) and that measured at the end of drilling was made.

Figure 9 shows that a linear relationship of coefficient of determination $\mathrm{R}^{2}=$ 0.8269 exists between the calculated and the measured alteration thicknesses. This good correlation is confirmed by the value of the Nash criterion of $76.76 \%$. This result of the Nash criterion justifies that the model is satisfactory, which means that the thicknesses of alterations calculated by the inverse slope method are close to $76.76 \%$ of those observed in the water drilling.

Despite the good correlation between calculated and measured thicknesses, there are, however, absolute errors in the results of the inverse slope method. Of the twenty-one (21) holes, we observed 8 drill holes with errors on the values of the calculated alteration thicknesses greater than 0.1 (Figure 10). These high errors corresponded to overestimated calculated alteration thicknesses compared to those measured during drilling.

\subsection{Discussion}

The prediction of the exact number of geoelectric layers and their thicknesses is a determining factor in the location of aquifers for drilling sites.

The interpretation of the electric sounding data by the inverse slope method gave a satisfactory result that was close to $76.76 \%$ of the corresponding drill hole

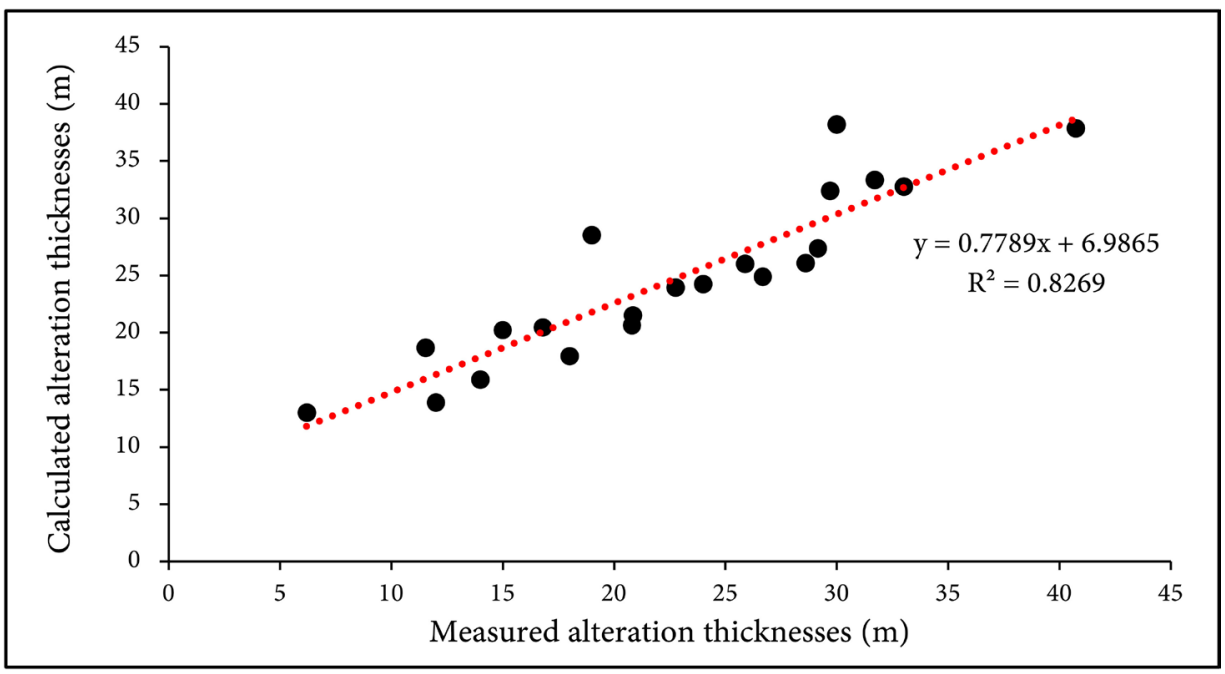

Figure 9. Relationship between the measured and calculated thicknesses of alterite. 


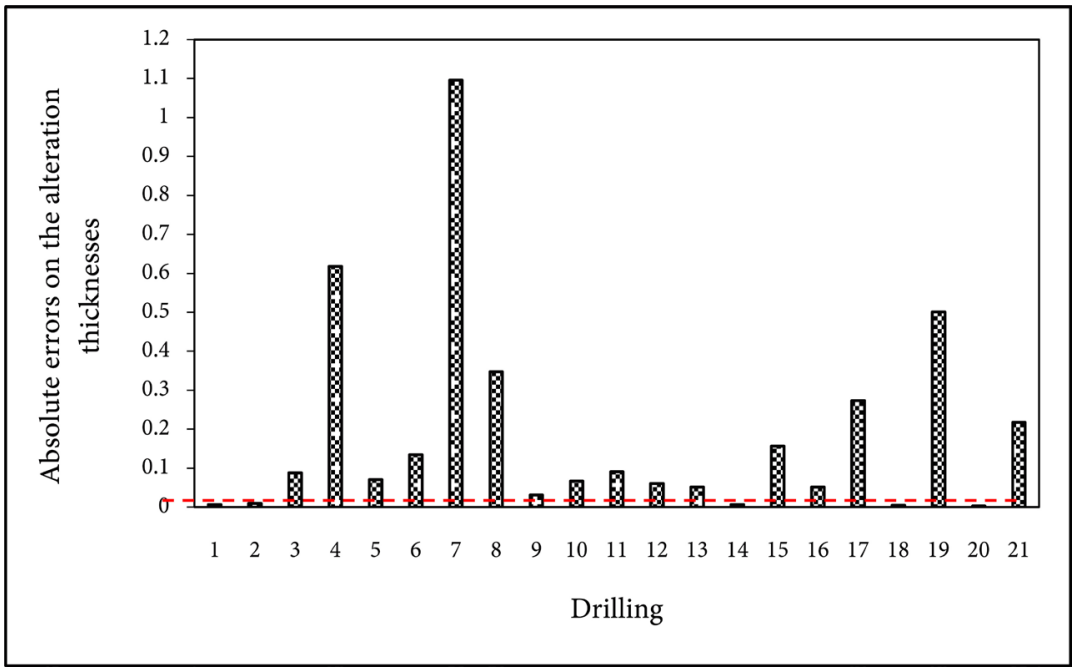

Figure 10. Absolute error tainted on the calculated thicknesses compared to those measured.

results. For a confirmation of the Nash value, the coefficient of determination of $\mathrm{R}^{2}=0.8269$ resulting from the relationship between the calculated thicknesses and those measured during the drillings justifies the good estimation of the thicknesses of the alterites by the inverse slope method. These results are consistent with those of Sanjiv (2010) and Aditya (2012) work at various sites in India and also with Asfahani (2016) in the phosphate sedimentary environments of the Al-Sharquieh mine in Syria.

In these same analyzes of the results of calculated and measured alteration thicknesses, the error rates observed between the calculated and measured alteration thicknesses are due to the fact that the geophysicist and the driller have a different way of approaching the geological formations of the subsoil. Indeed, from a geophysical point of view, the cracked fringe of bed-rock is an integral part of the conductive arenic level and the base consists exclusively of the underlying "compact" resistant zone (Savadogo, 1984; Dieng et al., 2004). On the other hand, the driller observes rather the cuttings pushed back from the drillings and the speed of advancement of the "hammer bottom of hole" to appreciate the different thicknesses/depths and natures of the geological formations crossed. These findings on the differences between calculated and measured alteration thicknesses were found in the research work of Coulibaly (2014) in the Tanda region and Kouassi et al. (2017) in the Nassian and Sominassé sub-prefectures. However, these gaps are not large enough to challenge the results of the inverse slope method, as this overestimation of alteration thicknesses does not have a significant influence on the implantation of water wells. Thus, the inverse slope method allows us to make qualitative and quantitative interpretations of electrical soundings. These interpretations are indicators in the choice of geophysical sites.

\section{Conclusion}

Finally, the results of interpretation of electrical soundings by the inverse slope 
method allowed us to count four (4) geoelectric layers and also showed that the thicknesses of alteration thicknesses are in the range of $12.99 \mathrm{~m}$ to $24.66 \mathrm{~m}$. Thus by comparing the calculated thicknesses of alteration thicknesses and those measured in the boreholes, the finding is that there is a concordance between them with a margin of error of $8.68 \%$ on the average. This is justified by a good linear relationship between the calculated EAs and measured EAs, with a Nash criterion that has shown that the inverse slope method is an acceptable model for interpretations of electrical sounding data.

As a result, thanks to its simplicity and easy implementation, the inverse slope method (ISM) allowed us to obtain quantitative results (true resistivities and thicknesses of the different layers) and qualitative results (the determination of the exact number of layers of the subsoil). Consequently, ISM can be complemented by the geophysicist with the other methods of interpretation of electrical soundings for a more detailed search of the geoelectric parameters of the geological structures in a crystalline basement zone.

\section{Acknowledgements}

This research was supported by the Hydrogeology Research Group of the Geosciences and Environment Laboratory at Nangui Abrogoua University in Abidjan, Ivory Coast. The constructive and valuable comments of the anonymous readers and the Editor-in-Chief of the Journal are greatly appreciated. The authors also thank Mr. Assoué Sylvestre KOUADIO for providing the drilling database.

\section{Conflicts of Interest}

The authors declare no conflicts of interest regarding the publication of this paper.

\section{References}

Aditya, K. B. (2012). An Assessment of Electrical Resistivity Soundings Data by Different Interpretation Techniques. International Journal of Biological, Ecological and Environmental Sciences, 1, 2277-4394.

Asfahani, J. (2016). Inverse Slope Method for Interpreting Vertical Electrical Soundings in Sedimentary Phosphatic Environments in the Al-Sharquieh Mine, Syria. CIM Journal, 7, 30. https://doi.org/10.15834/cimj.2016.12

Bakkali, S., \& Amrani, M. (2006). Un modèle 3D des "perturbations" des séries phosphatées basé sur l'optimisation des réponses du signal analytique des données de résistivité électrique. African Journal of Science and Technology, 7, 121-131. https://doi.org/10.4314/ajst.v7i1.55208

Baltassat, J. M., Grammare, M., Weng, P., Joseph, B., \& Laporte, P. (2005). Exploitation en eau souterraine par panneaux électriques et tests de sondages de Résonance Magnétique des Protons-Sites du mont Mahury et bourg de Cacao (communes de Rémire-Montjoly et de Roura, Guyane) (53 p.). Rapport final BRGM/RP-54169-FR décembre 2005.

Biemi, J. (1992). Contribution à l'étude géologique, hydrogéologique, et par télédé-tection 
des bassins versants subsaheliens du socle précambrien d'Afrique de l'Ouest: Hydrostructural, hydrodynamique et isotopie des aquifères discontinus de sillons et aires granitiques de la Marahoué (Cote d'Ivoire) (479 p.). Thèse de Doctorat d'Etat ès-Sciences Naturelles, Abidjan: Université de Cocody (Côte d'Ivoire).

Bodian, A., Dezetter, A., \& Dacosta, H. (2012). Apport de la modélisation pluie-débit pour la connaissance de la ressource en eau: Application au haut bassin du fleuve sénégal. Climatologie, 9, 109-125. https://doi.org/10.4267/climatologie.223

CGES Cadre de Gestion Environnementale et Sociale (2016). Projet de renaissance des infrastructures et de gestion urbaine en côte d'ivoire (PRICI). Financement addi-tionnel au projet d'urgence de renaissance des infrastructures financement: Don IDA $n^{\circ} H 79000-C I$ (p. 204).

Chapellier, D. (2001). Cours online géophysique, prospection électrique de surface $(97$ p.). Lausanne: Université de Lausanne; Institut Français du pétrole.

Clark, J. A., \& Page, R. (2011). Inexpensive Geophysical Instruments Supporting Groundwater Exploration in Developing Nations. Journal of Water Resource and Protection, 3, 768-780. https://doi.org/10.4236/jwarp.2011.310087

Collot, J. (2010). Séance 4: Prospection électrique. Géophysique marine. DEUST Géosciences. Service géologique DIMENC (pp. 1-18). Nouméa: Université de la Nouvelle Calédonie.

Coulibaly, A. (2014). Contribution de la méthode de résistivité électrique (Traînés et Sondages électriques) à la localisation d'aquifères en zone de socle cristallin et cristallophyllien: Cas de la région de Tanda, (Nord-est de la Côte d'Ivoire) (181 p.). Thèse de Doctorat, Abidjan: Université Félix Houphouët Boigny, Côte d'Ivoire.

Dieng, B., Kouassi, A. H., \& Bakyono, B. A. (2004). Optimisation de l'implantation géophysique des forages en zone de socle au Nord du Burkina Faso. Sud sciences et Technologies, No. 12, 21-30.

Ghosh, D. P. (1971). Inverse Filter Coefficients for Computation of Apparent Resistivity Standard Curves for a Horizontally Stratified Earth. Geophysical Prospecting, 19, 769-775. https://doi.org/10.1111/j.1365-2478.1971.tb00915.x

Karuppannan, S. (2015). Delineation of Groundwater Potential Zone by Using Geo-Physical Electrical Resistivity Inverse Slope Method in the Kadayampatty Panchayat Union, Salem District, Tamil Nadu. International Journal of Recent Scientific Research, 6, 5013-5017.

Kouadio, N. F. (2013). L'alimentation en eau potable des populations du Gontougo et du Bounkani: État des lieux et perspectives (p. 63). Ouagadougou: Master en ingénierie de l'eau et de l'environnement, 2IE.

Kouassi, F. W., Kouassi, K. A., Coulibaly, A., Kamagaté, B., \& Savané, I. (2017). Efficiency of Inverse Slope Method in the Interpretation of Electrical Resistivity Soundings Data of Schlumberger Type. International Journal of Engineering \& Science Research, 7, 121-130.

Marescot, L. (2004). Modélisation directe et inverse en prospection électrique sur des structures $3 D$ complexes par la méthode des éléments finis (208 p.). Thèse de doctorat ès Géosciences, Lausanne: Université de Nantes et de Lausanne.

Mondal, N. C., Das, S. N., \& Singh, V. S. (2008). Integrated Approach for Identification of Potential Groundwater Zones in Seethanagaram Mandal of Vizianagaram District, Andhra Pradesh, India. Journal of Earth System Science, 117, 133-144. https://doi.org/10.1007/s12040-008-0004-3

Mooney, H. M., \& Wetzel, W. W. (1956). The Potentials about a Point Electrode and 
Apparent Resistivity Curves for a Two-Three and Four Layered Earth (p. 146). Minneapolis, $M N$ : University of Minnesota Press.

Nash, J. E., \& Sutclife, J. V. (1970). River Flow Forecasting through Conceptual Models. Part I. A Discussion of Principles. Journal of Hydrology, 27, 282-290. https://doi.org/10.1016/0022-1694(70)90255-6

Orellana, E., \& Mooney, H. M. (1966). Master Tables and Curves of Vertical Electrical Sounding over Layered Structures (p. 193). Madrid: Interciencia.

Patra, H. P., \& Nath, S. K. (1999). Schlumberger Geoelectrical Sounding in Ground-Water: Principles, Interpretation and Application (p. 153). Rotterdam: A.A. Balkema and New Delhi: Oxford \& IHB Publishing Company.

Poongothai, S., \& Sridhar, N. (2017). Application of Geoelectrical Resistivity Technique for Groundwater Exploration in Lower Ponnaiyar Sub-Watershed, Tamilnadu, India. IOP Conference Series: Earth and Environmental Science, 80, Article ID: 012071. https://doi.org/10.1088/1755-1315/80/1/012071

Same, D. (1999). Hydrogéologie en zone de socle cristallin et cristallophyllien du Sénégal oriental. Application de la méthode électrique $1 D$ et $2 \mathrm{D}$ à la localisation et à la caractérisation des aquifères de batholites de Saraya et ses environs (133 p.). Thèse Doctorat 3éme cycle, Dakar: Université Cheik Anta Diop.

Sanjiv, K. S. (2010). Site Characterization Studies Using Electrical Resistivity Technique in Gudwanwadi Dam Site, Karjat, Maharashtra (p. 47). Master of Science in Applied Geophysics, Bombay: Department of Earth Science Indian Institute of Technology.

Sankarnaryan, P. V., \& Ramanujachary, K. R. (1967). An Inverse Slope Method for Determining Absolute Resistivities. Geophysics, 32, 1036-1040.

https://doi.org/10.1190/1.1439906

Savadogo, A. N. (1984). Géologie et hydrogéologie du socle cristallin de haute vol-ta: Etude régionale du bassin versant de la Sissili (350 p.). Thèse Doctorat ès sciences na-turelles, Grenoble: Université de Grenoble.

Sombo, A. P. (2012). Application des méthodes de résistivités électriques dans la détermination et la caractérisation des aquifères de socle en Côte d'Ivoire. Cas des départements de Sikensi et de Tiassale (Sud de la Côte d'Ivoire) (203 p.). Thèse de Doctorat, Abidjan: Université Félix Houphouët Boigny de Cocody.

Tagg, G. F. (1934). Interpretation of Resistivity Measurements. Transactions of the Metallurgical Society of AIME, 110, 135.

Tagini, B. (1971). Esquisse structurale de la Côte d'Ivoire. Essai de géotechnique regional (302 p.). Thèse Université de Lausanne (Suisse).

UNEP-GEF Volta Project (2008). Etude sur l'établissement d'un système régional d'échange des données et informations relatives au bassin versant de la Volta en Côte d'Ivoire. UNEP/GEF/Volta/NR RCI.2/2008.

Yao, B. K., Lasm, T., Ayral, P. A., Johannet, A., Kouassi, A. M., Assidjo, E., \& Biémi, J. (2007). Optimisation des modèles Perceptrons Multicouches avec les algorithmes de premier et de deuxième ordre. Application à la modélisation de la relation plu-ie-débit du Bandama Blanc, Nord de la Côte d'Ivoire. European Journal of Scientific Research, $17,13-328$. 


\section{Appendix}

Appendix 1: Summary of the Results of the Inverse Slope Method

\begin{tabular}{|c|c|c|c|c|c|c|c|c|c|c|}
\hline & & & Inve & rse slope & e method & & & & Thickn & of alterite \\
\hline & $a_{1}$ & $b_{1}$ & $a_{2}$ & $b_{2}$ & $a_{3}$ & $b_{3}$ & $a_{4}$ & $b_{4}$ & ISM & Drilling \\
\hline Equations & 0.0284 & -0.042 & 0.0066 & 0.2591 & -0.0016 & 0.5131 & & & & \\
\hline$\rho(\Omega \cdot \mathrm{m})$ & & 5.21 & 15 & & 62 & & & & 20.65 & 20.8 \\
\hline$H(\mathrm{~m})$ & & .21 & 11 & & & & & & & \\
\hline Equations & 0.049 & -0.008 & 0.015 & 0.225 & 0.007 & 0.383 & $5 \mathrm{E}-04$ & 0.616 & & \\
\hline$\rho(\Omega \cdot \mathrm{m})$ & & .45 & 68 & & 144 & & 20 & & 24.24 & 24 \\
\hline$H(\mathrm{~m})$ & & .54 & 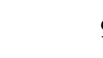 & & 10 & & & & & \\
\hline Equations & 0.003 & 0.023 & 0.012 & -0.106 & $-3 \mathrm{E}-04$ & 0.387 & & & & \\
\hline$\rho(\Omega \cdot \mathrm{m})$ & & 3.03 & 8 & & 333 & .33 & & & 26.08 & 28.6 \\
\hline$H(\mathrm{~m})$ & & 9.5 & 16 & & & & & & & \\
\hline Equations & 0.014 & -0.024 & $-6 \mathrm{E}-04$ & 0.394 & & & & & & \\
\hline$\rho(\Omega \cdot \mathrm{m})$ & & 9.93 & 166 & 5.67 & & & & & 18.67 & 11.54 \\
\hline$H(\mathrm{~m})$ & & 3.67 & & & & & & & & \\
\hline Equations & 0.025 & -0.044 & 0.003 & 0.111 & 0.007 & 0.018 & 0.002 & 0.296 & & \\
\hline$\rho(\Omega \cdot \mathrm{m})$ & & .32 & 38 & & 140 & & 454 & & 37.85 & 40.74 \\
\hline$H(\mathrm{~m})$ & & .66 & 9. & & 2 & & & & & \\
\hline Equations & 0.006 & -0.013 & 0.019 & -0.076 & $7 \mathrm{E}-04$ & 0.351 & & & & \\
\hline$\rho(\Omega \cdot \mathrm{m})$ & & 8.73 & 53 & & 1428 & & & & 15.89 & 14 \\
\hline$H(\mathrm{~m})$ & & .41 & 12 & & & & & & & \\
\hline Equations & 0.077 & -0.182 & 0.01 & 0.088 & $-9 \mathrm{E}-04$ & 0.321 & & & & \\
\hline$\rho(\Omega \cdot \mathrm{m})$ & & 3.05 & 97 & & 111 & .11 & & & 12.99 & 6.2 \\
\hline$H(\mathrm{~m})$ & & .71 & 10 & & & & & & & \\
\hline Equations & 0.0057 & -0.0226 & 0.0466 & -0.6132 & $7 \mathrm{E}-05$ & 0.7980 & & & & \\
\hline$\rho(\Omega \cdot \mathrm{m})$ & & 5.44 & 21 & & 1428 & 5.71 & & & 20.22 & 15 \\
\hline$H(\mathrm{~m})$ & & .63 & 10 & & & & & & & \\
\hline Equations & 0.013 & 0.041 & 0.036 & -0.171 & $-4 \mathrm{E}-04$ & 1.003 & & & & \\
\hline$\rho(\Omega \cdot \mathrm{m})$ & & 3.13 & 27 & & 25 & & & & 21.51 & 20.85 \\
\hline$H(\mathrm{~m})$ & & .09 & 15 & & & & & & & \\
\hline
\end{tabular}


R. A. M. Bouadou et al.

Appendix 2: Following Results of the Inverse Slope Method

\begin{tabular}{|c|c|c|c|c|c|c|c|c|c|}
\hline & \multicolumn{7}{|c|}{ Inverse slope method } & \multicolumn{2}{|c|}{ Thickness of alterite } \\
\hline & $b_{1}$ & $a_{2}$ & $b_{2}$ & $a_{3}$ & $b_{3}$ & $a_{4}$ & $b_{4}$ & ISM & Drilling \\
\hline Equations & $0.002 \quad 0.11$ & 0.015 & -0.11 & 0.015 & -0.076 & & & & \\
\hline$\rho(\Omega \cdot \mathrm{m})$ & 555.56 & \multicolumn{2}{|c|}{64.94} & \multicolumn{2}{|c|}{68.97} & & & 24.89 & 26.68 \\
\hline$H(\mathrm{~m})$ & 10.78 & \multicolumn{2}{|c|}{14.1} & & & & & & \\
\hline Equations & $0.045-0.067$ & $5 \mathrm{E}-04$ & 0.848 & -0.0012 & 0.93 & & & & \\
\hline$\rho(\Omega \cdot \mathrm{m})$ & 22.12 & \multicolumn{2}{|c|}{2000} & \multicolumn{2}{|c|}{833.33} & & & 32.39 & 29.7 \\
\hline$H(\mathrm{~m})$ & 13.64 & \multicolumn{2}{|c|}{18.75} & & & & & & \\
\hline Equations & $0.05-0.108$ & 0.004 & 0.587 & -0.0011 & 0.784 & & & & \\
\hline$\rho(\Omega \cdot \mathrm{m})$ & 19.92 & \multicolumn{2}{|c|}{270.27} & \multicolumn{2}{|c|}{909.09} & & & 27.38 & 29.15 \\
\hline$H(\mathrm{~m})$ & 9.97 & \multicolumn{2}{|c|}{17.4} & & & & & & \\
\hline Equations & $0.009-0.024$ & 0.049 & -0.593 & $2 \mathrm{E}-04$ & 0.85 & 0.011 & 0.325 & & \\
\hline$\rho(\Omega \cdot \mathrm{m})$ & 116.28 & \multicolumn{2}{|c|}{20.49} & \multicolumn{2}{|c|}{5000} & \multicolumn{2}{|c|}{93.46} & 33.34 & 31.71 \\
\hline$H(\mathrm{~m})$ & 9.45 & \multicolumn{2}{|c|}{10.35} & \multicolumn{2}{|c|}{13.54} & & & & \\
\hline Equations & $0.024-0.004$ & 0.004 & 0.089 & 0.019 & -0.335 & 0.001 & 0.51 & & \\
\hline$\rho(\Omega \cdot \mathrm{m})$ & 41.49 & & .16 & 54 . & & 769 & .23 & 32.77 & 33.01 \\
\hline$H(\mathrm{~m})$ & 3.05 & & 18 & 13. & & & & & \\
\hline Equations & $0.004-0.008$ & 0.016 & -0.098 & 0.001 & 0.217 & & & & \\
\hline$\rho(\Omega \cdot \mathrm{m})$ & 243.9 & & .73 & 909 & & & & 13.88 & 12 \\
\hline$H(\mathrm{~m})$ & 4.98 & & 91 & & & & & & \\
\hline Equations & $0.035-0.064$ & 0.008 & 0.336 & $-3 \mathrm{E}-05$ & 0.607 & & & & \\
\hline$\rho(\Omega \cdot \mathrm{m})$ & 28.25 & & .33 & 3333 & 3.33 & & & 23.93 & 22.76 \\
\hline$H(\mathrm{~m})$ & 9.57 & & .36 & & & & & & \\
\hline Equations & $0.007 \quad 0.091$ & 0.01 & 0.066 & 0.025 & -0.387 & 0.003 & 1.189 & & \\
\hline$\rho(\Omega \cdot \mathrm{m})$ & 138.89 & & .04 & 40. & & 370 & .37 & 38.2 & 30 \\
\hline$H(\mathrm{~m})$ & 6.21 & & .94 & 18. & & & & & \\
\hline Equations & $0.007 \quad 0.006$ & 0.036 & -0.393 & 0.002 & 0.941 & & & & \\
\hline$\rho(\Omega \cdot \mathrm{m})$ & 144.93 & & 62 & 50 & & & & 26 & 25.88 \\
\hline$H(\mathrm{~m})$ & 9.07 & & 93 & & & & & & \\
\hline Equations & $0.003 \quad 0.029$ & 0.002 & 0.029 & 0.008 & -0.088 & 0.005 & 0.04 & & \\
\hline$\rho(\Omega \cdot \mathrm{m})$ & 400 & & .56 & 131 & & 217 & 7.39 & 28.51 & 19 \\
\hline$H(\mathrm{~m})$ & 0.29 & & 15 & 15 . & & & & & \\
\hline Equations & $0.019-0.027$ & 0.031 & -0.07 & 0.005 & 0.629 & & & & \\
\hline$\rho(\Omega \cdot \mathrm{m})$ & 54.05 & & .79 & 222 & & & & 17.94 & 18 \\
\hline$H(\mathrm{~m})$ & 2.42 & & 52 & & & & & & \\
\hline Equations & $0.008-0.018$ & 0.106 & -0.771 & 0.011 & 0.697 & 0.002 & 1.081 & & \\
\hline$\rho(\Omega \cdot \mathrm{m})$ & 119.05 & & 48 & 93. & & 555 & .56 & 20.46 & 16.8 \\
\hline$H(\mathrm{~m})$ & 5.17 & & 15 & 10. & & & & & \\
\hline
\end{tabular}

